\title{
MENINGKATKAN PRESTASI BELAJAR MATEMATIKA DENGAN METODE PROBLIM BASED LEARNING PADA POKOK BAHASAN LOGIKA MATEMATIKA DI KELAS X-1 SMA
}

\author{
Ibnu Mualam \\ ibnumualam@gmail.co.id
}

\begin{abstract}
Abstrak
Melalui kegiatan pembelajaran dengan model Problim Based Learning diharapkan prestasi belajar peserta didik meningkat, Dari ketiga siklus menunnjukkan prestasi belajar peserta didik . Dapat disimpulkan metode problem based learning dapat meningkatkan prestasi belajar peserta didik. Dari 32 peserta didik didapatkan data nilai pada akhir pelaksanaan tindakan pada setiap siklus tampak ada peningkatan pembelajaran dan hasil pembelajaran disetiap siklus meningkat pula yaitu nilai rata-rata sebelum diadakan penelitian 42,8, pada siklus I 69,4 dan pada siklus II 74,4 dengan prosentase kenaikan nilai rata-rata ulangan harian sebelum diadakan PTK ke siklus I naik 62,15\% dari siklus I ke siklus II naik 7,20 \%. Jadi dapat disimpulkan bahwa penggunaan metode Problem-Based Learning dalam pembelajaran matematika pada pokok bahasan logika matematika dapat meningkatkan prestasi belajar matematika.
\end{abstract}

Kata kunci: Logika, Problem-Based Learning

\section{PENDAHULUAN}

Kurikulum berganti berulang kali tetapi kualitas pendidikan matematika di Indonesia sampai sekarang tidak bisa meningkat secara segnifikan. Hal ini antara lain terjadi karena proses pembelajaran yang mekanistik dan asesmennya yang mengutamakan obyektivitas tidak pernah berubah secara segnifikan (Marpaung, 2003:1). Seorang guru yang dianggap ujung tombak masih belum mampu merubah kebiasaan mengajar dari paradigma mengajar keparadigma belajar. Pada hal paradigma mengajar sama sekali tidak mengarah siswa untuk menigkatkatkan kemmampuannya dalam meningkatkan konsep.

Keberhasilan pembelajaran dalam arti tercapainya standar kompetensi, sangat bergantung pada kemampuan guru mengolah pembelajaran yang dapat menciptakan situasi yang memungkinkan siswa belajar sehingga merupakan titik awal berhasilnya pembelajaran (Semiawan, 1985).

Pembelajaran berbasis masalah merupakan jawaban terhadap praktek pembelajaran kompetensi serta merespon perkembangan dinamika sosial masyarakat. Selain itu pembelajaran berbasis masalah pada dasarnya merupakan pengembangan lebih lanjut dari pembelajaran kelompok. Dengan demikian, metode pembelajaran berbasis masalah memiliki karakteristik yang khas yaitu menggunakan masalah dunia nyata sebagai konteks belajar bagi siswa untuk belajar tentang berpikir kritis dan ketrampilan memecahkan masalah, serta untuk memperoleh pengetahuan dan konsep esensial dari materi pelajaran.

Tujuan penelitian ini untuk mengetahui (1) peningkatan kemampuan siswa dalam menyelesaikan soal-soal pada pokok bahasan Logika Matematika di kelas X SMA Negeri I Turen Tahun Ajaran 2011- 
2012 yang diajarkan dengan metode Problem-based Learning, (2) peningkatan prestasi belajar siswa pada pokok bahasanLogika Matematika di kelas X-1 SMA Negeri I Turen Tahun Ajaran 20112012 yang diajarkan dengan metode Problem-Based Learning, (3) dampak metode Problem-Based Learning dalam meningkatkan prestasi belajar siswa $\mathrm{X}-1$ SMA Negeri I Turen Tahun Ajaran 20112012 pada pokok bahasan Logika Matematika.

Belajar pada prinsipnya adalah proses perubahan tingkah laku sebagai akibat dari interaksi antara siswa dengan sumber-sumber atau obyek belajar baik secara sengaja dirancang atau tanpa sengaja dirancang (Suliana,2005). Kegiatan belajar tersebut dapat dihayati (dialami) oleh orang yang sedang belajar. Selain itu kegiatan belajar juga dapat di amati oleh orang lain. Belajar yang di hayati oleh seorang pebelajar (siswa) ada hubungannya dengan usaha pembelajaran, yang dilakukan oleh pembelajar (guru).

\section{METODE}

Penelitian dilaksanakan di SMA Negeri I Turen pada kelas X-1 semester ganjil tahun pelajaran 2011/2012 dengan pokok bahasan Logika Matematika dengan Metode Problem-Based Learning. SMA Negeri I Turen adalah salah satu sekolah negeri termuda yang berada dibawah Dinas Pendidikan Daerah Kota Turen yang beralamatkan di Jl. Majen Panjahitan 65 Turen. Penelitian menggunakan metode Penelitian Tindakan Kelas (PTK) dengan rancangan sebagai berikut.

\section{Perencanaan ( Planning)}

Dalam tahap Perencanaan Peneliti bersama Kolaborator mempersiapkan Silabus Soal-soal ulangan harian, Instrumen penelitian Materi dan rancangan pembelajaran yaitu Logika Matematika

\section{Pelaksanaan (Acting)}

Tahap pelaksanaan dilaksanakan didalam kelas dengan melakukan kegiatan pembelajaran sesuai dengan silabus yang telah direncanakan. Peneliti membimbing siswa dalam menyelesaikan soal Logika Matematika dengan pendekatan ProblemBased Learning membentuk suatu diskusi kelompok kecil. Peneliti memberi kesempatan kepada siswa untuk bertanya, Sementara Kolaborator mengamati proses pembelajaran sebagai bahan diskusi selanjutnya

\section{Pengamatan (Observing)}

Kolaborator melakukan pengamatan terhadap kegiatan siswa, baik tentang sikap maupun tingkah laku selama kegiatan pembelajaran maupun saat mempresentasikan hasil kerja kelompoknya

\section{Refleksi ( Reflecting)}

Dalam tahap ini merupakan kegiatan menganalisa, mensintesa dari hasil pengamatan selama proses pembelajaran pada siklus I berlangsung dan diadakan ulangan harian yang digunakan untuk mengetahui hasil belajar baik secara individu maupun klasikal.Bila ternyata pada tahap ini seluruh siswa telah mencapai standart ketuntasan minimal, maka langsung dilanjutkan dengan siklus II.

Pengumpulan data dengan menggunakan test, angket dan observasi. Ketuntasan Perorangan.Seorang siswa dikatakan berhasil (mencapai ketuntasan) belajar bila telah mencapai taraf penguasaan 
minimal $60 \%$ atau dengan nilai 60. Bagi siswa yang taraf penguasaannya kurang dari $60 \%$ diberikan remidi pada pokok bahasan yang belum dikuasai, sedangkan bagi siswa yang telah mencapai penguasaan $60 \%$ atau lebih dapat melanjutkan kepokok bahasan berikutnya.Ketuntasan KlasikalSuatu kelas dikatakan telah berhasil (mencapai ketuntasan belajar) jika paling sedikit $85 \%$ data jumlah siswa dalam kelas tersebut telah mencapai ketuntasan perorangan dengan ketentuan sebagai berikut :Apabila sudah terdapat $85 \%$ dari jumlah siswa keseluruhan dalam kelas yang mencapai tingkat ketuntasan belajar maka kelas tersebut dapat melanjutkan kegiatan pada satuan pembelajaran berikutnya.

Apabila jumlah siswa yang mencapai tingkat ketuntasan belajar masih kurang dari $85 \%$ maka: Siswa yang taraf penguasaannya kurang dari $60 \%$ harus diberi program perbaikan mengenai bagian-bagian pelajaran yang belum dikuasai.Siswa yang telah mencapai taraf penguasaan $60 \%$ atau lebih dapat diberikan program pengayaan.Untuk menentukan prosentase dari pencapaian ketuntasan siswa maupun kelas adalah sebagai berilut:

Prosentase ketuntasan siswa $=\frac{s p}{s t} \times 100 \%$

Prosentase ketuntasan kelas $=\frac{\Sigma s}{\Sigma t} \times 100 \%$

Keterangan: $\mathrm{sp}=$ skor perolehanst $=$ skor total $\Sigma \mathrm{s}=$ jumlah siswa yang mencapai ketuntasan $\Sigma \mathrm{t}=$ jumlah siswa total dalam kelas Jika dalam suatu kelas ketuntasan siswa lebih atau sama dengan $85 \%$ maka pembelajaran yang dilaksanakan guru dapat dikatakan berhasil. Tetapi jika ketuntasan siswa kurang dari $85 \%$ maka pembelajaran yang dilaksanakan guru belum berhasil dan perlu diperhatikan mengenai metode dalam pembelajarannya.

\section{HASIL DAN PEMBAHASAN}

Sebagaimana dibahas dalam bab III tentang metodologi penelitian maka tahapan penelitian tindakan ini berupa siklus-siklus. Adapun pelaksanaan dari siklus-siklus tersebut adalah sebagai berikut:

\section{Siklus I}

\section{Perencanaan}

Guru melaksanakan kegiatan pembelajaran sesuai yang direncanakan dengan Kolaborator dengan bentuk klasikal. Siswa duduk berkelompok sesuai dengan tempat duduk yang berdekatan dalam satu garis bangku dengan anggota 4-5 orang.Guru memberikan tugas secara berkelompok dan individu. Guru mengamati proses berlangsungnya belajar kelompok. Kolaborator membuat catatan pribadi (catatan lapangan). Guru memberikan tes kepada siswa.

\section{Pelaksanaan}

Pelaksanaan pembelajaran siklus I dilaksanakan pada tanggal 23 Oktober 2008 yang pelaksanaannya sebagai berikut: Setelah tanda pelajaran dimulai Peneliti masuk ke kelas X-I yang dipilih untuk obyek penelitian. Peneliti mengucapkan salam kemudian dibahas tentang pernyataan dan kalimat terbuka. Peneliti memberikan pertanyaan-pertanyaan tentang pernyataan dan kalimat terbuka dengan tujuan untuk mengetahui sejauh mana pengetahuan siswa tentang pernyataan dan kalimat terbuka. Selain diharapkan dapat membangkitkan kreativitas siswa dalam mengungkapkan pendapat dan apa yang siswa ketahui tentang pernyataan dan kalimat terbuka. Kemudian siswa disuruh menyebutkan contoh-contoh 
pernyataan dan kalimat terbuka dalam kehidupan sehari-hari.

Peneliti memberikan kesempatan kepada siswa untuk bertanya tentang apa yang belum difahami. Kemudian Peneliti menerangkan apa yang belum dimengerti oleh siswa sehingga siswa menjadi faham. Apabila siswa telah paham, maka Peneliti memberikan soal-soal untuk dikerjakan. Terlebih dahulu siswa disuruh membentuk kelompok secara heterogen yang beranggotakan 4-5 orang dan soal tersebut dikerjakan secara berkelompok. Peneliti mengamati dan berkeliling untuk memberikan bimbingan bagi siswa yang masih mengalami kesulitan. Selanjutnya Peneliti menunjuk siswa untuk mengerjakan kedepan dari hasil pekerjaan yang telah dikerjakan.

Sebelum kegiatan pembelajaran pertama berakhir, Peneliti memberikan soalsoal latihan (evaluasi 1) yang harus dikerjakan siswa dan selanjutnya dikumpulkan. Dari hasil latihan ini dijadikan sebagai sumber data pertama. Pada kegiatan ini soal yang Peneliti berikan berjumlah 2 butir soal dengan nomor 1 (a sampai dengan e) dan nomor 2 (a sampai dengan e) dengan alokasi waktu 30 menit.

\section{Pengamatan}

Berdasarkan dari catatan lapangan, pada saat berlangsungnya belajar kelompok ada diantara salah satu kelompok yang dua anggotanya bercengkerama sendiri tentang hal diluar materi diskusi. Peneliti menegur dan menyuruh untuk aktif berinteraksi dengan kelompoknya dalam mendiskusikan masalah yang telah diberikan oleh Peneliti. Sementara itu ada seorang siswa yang makan makanan ringan didalam kelas kemudian ditegur oleh Peneliti. Pada setiap kelompok yang antusias membahas tugas yang diberikan rata-rata 2 atau 3 orang sedang anggota lain cukup aktif.

Pengamatan diluar proses belajar kelompok yaitu Peneliti memeriksa buku catatan masing-masing siswa setelah penyajian materi. Ternyata ada beberapa siswa yang tidak mencatat dengan berbagai alasan. Ditinjau dari ketuntasan siswa, diperoleh data sebagai berikut: (a) ketuntasan belajar Banyak siswa seluruhnya 40 siswa Banyak siswa yang tuntas belajarnya 40 siswa. Prosentase banyaknya siswa yang tuntas $100 \%$

Kesimpulan: tidak perlu diadakan perbaikan karena siswa tuntas semua, perlu perbaikan pengajaran untuk soal no. 4, 5 dan 8 .

Dari analisa diatas dapat diambil kesimpulan bahwa kegiatan pembelajaran yang telah dilakukan telah berhasil sebab prosentase siswa yang tuntas belajar mencapari $100 \%$ dari siswa kelas X-1. Suatu kelas dikatakan berhasil jika mencapai ketuntasan belajar minimal $85 \%$ dari jumlah siswa dalam kelas tersebut. Hal ini menunjukkan bahwa kegiatan pembelajaran telah berhasil dan dapat dilanjutkan ke tahap pembelajaran berikutnya. Sedangkan dari soal yang diberikan, ternyata soal no. 4, 5 dan 8 perlu mendapatkan perbaikan karena dari skor yang tercapai ada $33 \%$ untuk soal no. $4,48 \%$ untuk soal no. 5 dan $35 \%$ untuk soal no. 8. Nilai rata-rata secara klasikal adalah 69,3

Hasil pengamatan kinerja pada bagian pendahuluan, penutup dan situasi kelas termasuk kategori cukup. Tetapi pada bagian tertentu misalnya ketrampilan mengarahkan siswa untuk menjawab soal, mengamati cara siswa menyelesaikan masalah masih perlu ditingkatkan lagi. Dari 
hasil pengamatan kinerja guru pada siklus I masih diperlukan upaya dalam memotivasi siswa, menghubungkan dengan pelajaran yang telah lalu dan memberikan waktu yang cukup kepada siswa yang belum selesai mengerjakan soal. Hasil pengamatan pada siklus I entang kinerja dapat dilihat pada tabel berikut.

Refleksi Perbaikan dan Pengayaan berdasarkan hasil pelaksanaan dan pengamatan pada siklus I ditemukan kegagalan. Dilihat dari perolehan nilai tes, siswa yang memperoleh nilai baik $(90-100)$ adalah 7 orang $(17 \%)$, yang memperoleh nilai cukup $(60$ - 89) adalah 33 siswa (83\%), tetapi yang memperolah nilai kurang $(0-59)$ tidak ada $(0 \%)$.Dilihat dari keaktifan mencatat materi yang diberikan, siswa yang tidak aktif mencatat ada 7 orang $(17 \%)$ dari 40 siswa.Dilihat dari keaktifan siswa dalam belajar kelompok, siswa yang tidak aktif ada 7 siswa $(17 \%)$ dari 40 siswa.

\section{Siklus II}

\section{Perencanaan}

Pada siklus II Peneliti lebih meningkatkan kegiatan pembelajaran dari apa yang telah dilakukan pada siklus I yaitu ingin meningkatkan kreatifitas siswa kelas X-1 SMA Negeri I TUREN dalam pembelajaran kelompok. Adapun perencanaannya adalah sebagi berikut.

Peneliti menyajikan materi pelajaran yang telah dirancang bersama Kolaborator siswa diminta belajar kelompok untuk membahas penyelesaian soal-soal Logika Matematika .Peneliti memberikan tugas secara berkelompok dan individu.

Siswa diberi kesempatan secara kelompok untuk menanyakan hal-hal yang belum jelas,Peneliti memberikan bimbingan kepada setiap kelompok yang mengalami kesulitan menyelesaikan soal-soal logika matematika.Kolaborator membuat catatan pribadi Peneliti memberikan tes dan angket kepada siswa.

\section{Pelaksanaan}

Siklus II dilaksanakan pada tanggal 30 Oktober 2011 yang membahas tentang disjungsi dan konjungsi. Adapun pelaksanaanya sama seperti siklus I tetapi dimodifikasi sedikit lebih menekankan pada kreativitas siswa dalam belajar. Setelah menyampaikan materi berkenaan dengan disjungsi dan konjungsi kemudian Peneliti memberikan soal di papan tulis.

Peneliti membagi semua siswa dalam kelompok heterogen yang tediri atas $4-5$ orang tiap kelompok :Tiap orang dalam masing-masing kelompok membuat soalsoal yang ada hubungannya dengan pokok bahasan seperti ng dicontohkan di papan tulis.Membicarakan soal yang telah dibuat masing-masing orang dalam kelompok.

Mendiskusikan soal yang dipilih sebagai soal kelompoknya Masing-masing anggota kelompok mengerjakan soal berdasarkan pertanyaan hasil kesepakatan. Masing-masing Kelompok mempresentasikan hasil kerjanya menggunakan Laptop dan LCD yang tersedia di ruang Multimedia. Dengan tugas yang terstuktur tersebut diharapkan mereka belajar bagaimana menggunakan pertanyaan untuk membantu mereka dalam merencanakan, memantau dan mengevaluasi pemecahan masalah yang mereka hadapi. Hal serupa dilakukan oleh kelompok-kelompok lain dalam kelas tersebut. Setelah masing-masing kelompok mendiskusikan kegiatan diatas, masingmasing anggota kelompok berusaha untuk menjawab soal berdasarkan pertanyaan hasil diskusi kelompok. Sedangkan siswa sedang 
membuat jawaban soal secara individu, Peneliti berkeliling memantau kemajuan siswa, antara lain memeriksa apakan siswa sudah bekerja sesuai dengan rencana atau belum. Jika Peneliti mendapati siswa menemui kesulitan, maka Peneliti perlu memberi bantuan antara lain mengingatkan langkah-langkah penyelesaiaan soal, yaitu perencanaan, pelaksanaan, pemantauan dan evaluasi. Jawaban masing masing kelompok didiskusikan dalam kelompok tersebut.

Secara acak Peneliti menunjuk beberapa kelompok tersebut untuk presentasikan penyelesaiaanya dan menjelaskan kepada semua siswa tentang proses penyelesaian soal yang dikerjakan dengan bantuan Laptop dan LCD yang disediakan di ruang Multimedia. Peneliti membantu siswa yang menemui kesulitan atau meluruskan hasil presentasi yang menyimpang. Sebelum kegiatan pembelajaran berakhir, peneliti memberikan soal-soal latihan (evaluasi 2) yang harus dikerjakan siswa dan selanjutnya diberikan angket untuk diisi oleh siswa.

\section{Pengamatan}

Berdasarkan catatan lapangan, pada saat berlangsungnya belajar kelompok pada awalnya setiap siswa kelihatan aktif dalam kelompoknya masing-masing. Hal ini disebabkan karena Peneliti berkeliling melihat-lihat cara kerja masing-masing kelompok, secara bergantian Peneliti membimbing bagai mana cara yang benar dalam menyelesaikan soal-soal logika yang diberikan. Pada saat bersamaan, sewaktu Peneliti memberikan bimbingan kepada kelompok III ada seorang dari kelompok I sedang makan makanan ringan dan Peneliti menegurnya supaya aktif berinteraksi dengan kelompoknya.
Adapun pengamatan diluar proses belajar kelompok yaitu Peneliti memeriksa catatan setiap siswa setelah materi diberikan.Ternyata ada seorang siswa yang tidak mencatat.Ditinjau dari keaktifan siswa dalam belajar kelompok melalui lembar catatan lapanganHasil Analisa

Ketuntasan belajar Banyak siswa seluruhnya 40 siswa Banyak siswa yang tuntas belajarnya 40 siswa Prosentase banyaknya siswa yang tuntas $100 \%$. Kesimpulan, tidak perlu diadakan perbaikan karena siswa tuntas semuaPerlu perbaikan pengajaran untuk soal no. 4, 5 dan 8 .

Dari analisa diatas dapat diambil kesimpulan bahwa kegiatan pembelajaran yang telah dilakukan telah berhasil sebab prosentase siswa yang tuntas belajar mencapai $100 \%$ dari siswa kelas X-1. Suatu kelas dikatakan berhasil jika mencapai ketuntasan belajar minimal $85 \%$ dari jumlah siswa dalam kelas tersebut. Hal ini menunjukkan bahwa kegiatan pembelajaran telah berhasil dan dapat dilanjutkan ke tahap pembelajaran berikutnya. Sedangkan dari soal yang diberikan, ternyata soal no. 4, 5 dan 8 perlu mendapatkan perbaikan karena dari skor yang tercapai ada $33 \%$ untuk soal no. $4,48 \%$ untuk soal no. 5 dan $35 \%$ untuk no. 8. Nilai rata-rata secara klasikal adalah 69,3. Ditinjau dari perolehan nilai hasil tes datanya dapat dilihat pada tabel Hasil pengamatan kinerja pada bagian pendahuluan, penutup dan situasi kelas termasuk kategori cukup. Tetapi pada bagian tertentu misalnya ketrampilan mengarahkan siswa untuk menjawab soal, mengamati cara siswa menyelesaikan masalah masih perlu ditingkatkan lagi. Dari hasil pengamatan kinerja guru pada siklus I masih diperlukan upaya dalam memotivasi siswa, 
menghubungkan dengan pelajaran yang telah lalu dan memberikan waktu yang cukup kepada siswa yang belum selesai mengerjakan soal.

Hasil pengamatan pada siklus I tentang kinerja dapat dilihat berikut.

\section{Refleksi Perbaikan dan Pengayaan}

Berdasarkan hasil pelaksanaan dan pengamatan pada siklus I ditemukan kegagalan yaitu:

a. Dilihat dari perolehan nilai tes, siswa yang memperoleh nilai baik $(90-100)$ adalah 7 orang (17\%), yang memperoleh nilai cukup $(60-89)$ adalah 33 siswa (83\%), tetapi yang memperolah nilai kurang $(0-59)$ tidak ada $(0 \%)$.

b. Dilihatdari keaktifan menggunakan media pembelajaran, siswa yang tidak aktif menggunakan media pembelajaran ada 7 orang ( $17 \%$ ) dari 40 siswa.

Dilihat dari keaktifan siswa dalam belajar kelompok, siswa yang tidak aktif ada 7 siswa (17\%) dari 40 siswa

Meskipun nilai siswa pada siklus I ke siklus II ada yang mengalami peningkatan dan ada yang mengalami penurunan tetapi semua sudah mencapai ketuntasan. Dengan demikian pelaksanaan siklus II dikatakan berhasil.Setelah pembelajaran diberikan angket yang hasilnya adalah sebagai berikut : Dari hasil penelitian tindakan kelas selama siklus I sampai dengan siklus II dilakukan pengelompokan hasil-hasil nilai ulangan harian. Hal ini agar lebih mudah menganalisanya. Sedangkan analisa data dilakukan dengan menggunakan teknik statistik sederhana yaitu dengan menggunakan analisa diskriptif. Analisa diskriptif adalah model analisa dengan cara membandingkan rata-rata prosentasenya. Kemudian kenaikan rata-rata pada tiap-tiap siklus. Hasil analisa hari keseluruhan siklus adalah sebagai berikut.

\section{Hasil Analisa}

Kenaikan prosentase rata-rata PRA PTK dan siklus I

$\mathrm{T}=\frac{\text { PostRate }- \text { BaseRate }}{\text { BaseRate }} \times 100 \%$

$=\frac{(69,3-42,8)}{42,8 \times 100 \%}=62,9 \%$

Kenaikan prosentase siklus I dan siklus II

$\mathrm{T}=\frac{\text { PostRate }- \text { BaseRate }}{\text { BaseRate }} \times 100 \%$

$=\frac{(74,3-69,3)}{69,3 \times 100 \%}=7,2 \%$

Dari hasil analisa diatas diperoleh kenaikan siklus yaitu sebagai berikut: Rata-rata kenaikan siklus I dibanding rata-rata nilai ulangan PRA PTK naik 62,9 \%. Rata-rata nilai ulangan siklus II dibanding rata-rata nilai ulangan siklus I naik 7,2 \%.

Dari hasil kenaikan rata-rata diatas juga dapat dilihat kenaikan prosentase secara keseluruhan sebagai berikut.

Tabel 13. Data Hasil Kenaikan Nilai Ulangan Secara Keseluruhan

\begin{tabular}{|l|l|l|l|l|l|}
\hline No & Uraian & $\begin{array}{l}\text { Pra } \\
\text { PTK }\end{array}$ & $\begin{array}{l}\text { Siklus } \\
\text { I }\end{array}$ & $\begin{array}{l}\text { Siklus } \\
\text { II }\end{array}$ & Kenaikan \\
\hline 1 & $\begin{array}{l}\text { Rata-rata } \\
\text { Kenaikan } \\
\text { nilai tiap } \\
\text { siklus }\end{array}$ & 42.8 & 69.3 & 74.3 & 31.5 \\
\hline
\end{tabular}

Dari tabel diatas dapat dijelaskan bahwa penghitungan kenaikan keberhasilan secara keseluruhan diperoleh dari rata-rata setelah diadakan PTK atau siklus II dikurangi ratarata sebelum diadakan PTK.

Dengan analisa $=74,3-42,8=31,5$. Hasil analisa dari distribusi frekuensi perolehan 
nilai dari keseluruhan siklus adalah sebagai berikut.

Tabel 14. Data Hasil Distribusi Frekuensi Perolehan Nilai dari Siklus I dan Siklus II

\begin{tabular}{|l|l|l|l|}
\hline No & Uraian & Siklus I & Siklus II \\
\hline 1 & Nilai $<90$ & 33 & 29 \\
2 & Nilai $\geq 90$ & 7 & 11 \\
\hline
\end{tabular}

Hasil Analisa

Kenaikan prosentase perolehan nilai siklus I dan siklus II, untuk nilai $<90$.

$\mathrm{T}=\frac{\text { PostRate }- \text { BaseRate }}{\text { BaseRate }} \times 100 \%$

$=\frac{29-33}{33} \times 100 \%$

$=-12,12 \%$ Untuk nilai $\geq 90$

$\mathrm{T}=\frac{\text { PostRate }- \text { BaseRate }}{\text { BaseRate }} \times 100 \%$

$=\frac{11-7}{7} \times 100 \%=57,14 \%$

Dari hasil analisa diatas diperoleh: untuk nilai < 90 antara siklus I dan siklus II mengalami penurunan yaitu sebesar $-12,12$ $\%$.

Untuk nilai $\geq 90$ antara siklus I dan siklus II mengalami kenaikan sebesar 57,14\%Hasil analisa dari keaktifan siswa menggunakan media pembelajaran dari keseluruhan siklus adalah sebagai berikut.

Tabel 15. Data Hasil Kreatifitas Siswa Menggunakan media pembelajaran

Siklus I \& Siklus II.

\begin{tabular}{|l|l|l|l|}
\hline No & Keaktifan & Siklus I & Siklus II \\
\hline 1 & Aktif & 33 & 38 \\
2 & Cukup Aktif & 7 & 2 \\
\hline
\end{tabular}

Hasil Analisa Kanaikan prosentase dalam menggunakan media pembelajaran antara siklus I dan siklus II Untuk siswa aktif.
$\mathrm{T}=\frac{\text { Postrate }- \text { Baserate }}{\text { Baserate }} \times 100 \%$

$=\frac{38-33}{33} \times 100 \%=15,15 \%$

Untuk siswa tidak aktif

$\mathrm{T}=\frac{\text { Postrate }- \text { Baserate }}{\text { Baserate }} \times 100 \%$

$=\frac{2-7}{7} \times 100 \%=-71,42 \%$.

Dari hasil analisa diatas diperoleh:Untuk keaktifan siswa dalam menggunakan media pembelajaran antara siklus I dan siklus II mengalami kenaikan yaitu sebesar 15,15 \%Untuk siswa tidak aktif dalam menggunakan media pembelajaran antara siklus I dan siklus II mengalami penurunan yaitu sebesar $-71,42$ \% Hasil analisis keaktifan siswa dalam belajar kelompok antara siklus I dan siklus II adalah sebagai berikut. Untuk siswa aktif hasil Analisa sebagai berikut.

$\mathrm{T}=\frac{\text { Postrate }- \text { Baserate }}{\text { Baserate }} \times 100 \%$

$=\frac{33-22}{22} \times 100 \%$

$=50 \%$

Untuk siswa cukup aktif

$\mathrm{T}=\frac{\text { Postrate }- \text { Baserate }}{\text { Baserate }} \times 100 \%$

$=\frac{7-11}{5} \times 100 \%=-36,36 \%$

Untuk siswa tidak aktif

$\mathrm{T}=\frac{\text { Postrate }- \text { Baserate }}{\text { Baserate }} \times 100 \%$

$=\frac{0-7}{7} \times 100 \%=-100 \%$.

Keaktifan siswa dalam belajar kelompok antara siklus I dan siklus II mengalami kenaikan yaitu sebesar 50 \%Untuk siswa cukup aktif dalam belajar kelompok antara siklus I dan siklus II mengalami penurunan 
yaitu sebesar -40 \%Untuk siswa tidak aktif dalam belajar kelompok antara siklus I dan siklus II mengalami penurunan yaitu sebesar -100\%Meskipun dalam PTK ini dalam siklus I dan siklus II semua siswa tuntas semua, maka PTK tetap dilaksanakan pada siklus-siklus berikutnya karena untuk mengetahui sejauh mana kemampuan siswa dalam menerima materi pelajaran dan untuk mengetahui kesulitan apa yang dihadapi siswa dalam menerima materi pelajaran.

\section{PENUTUP}

\section{Kesimpulan}

Setelah Peneliti cermati selama dalam kegiatan Penelitian Tindakan Kelas dari proses sampai diperoleh hasil, maka Peneliti menyimpulkan sebagai berikut :Dengan metode Problem-Based Learning dapat meningkatkan kemampuan siswa dalam menyelesaikan soal-soal latihan pada pokok bahasan logika matematika di kelas X-1 SMA Negeri I Turen Tahun Ajaran 2011 - 2012.Dengan menggunakan metode Problem-Based Learning prestasi belajar siswa kelas X-1 SMA Negeri I Turen Tahun Ajaran 2011 - 2012 pada pokok bahasan Logika Matematika menjadi lebih baik. Hal ini dapat dilihat dari perolehan nilai rata-rata ulangan harian yang semula sebelum diadakan penelitian 42,8 dengan ketuntasan $43 \%$. pada siklus I 69,3 dengan ketuntasan $69 \%$ dan pada siklus II 74,3 dengan ketuntasan $74 \%$

Problem-Based Learning pada pokok bahasan logika matematika telah memberikan nuansa baru dalam pembelajaran matematika sehingg pembelajaran lebih efektif. Hal ini terlihat pada saat belajar siswa lebih kreatif, aktif, bertanggung jawab dan bekerja sama dalam kelompok dan juga dari jawaban terhadap angket tentang metode pembelajaran Problem-Based Learning yang diisi siswa.

\section{Saran}

Berdasarkan hasil penelitian tindakan kelas yang peneliti laksanakan dapat dikemukakan saran yang bermanfaat bagi peneliti selanjutnya ataupun guru sebagai berikut :Pembelajaran matematika hendaknya bervariasi dan tidak monoton sehingga hasil pembelajaran dapat lebih maksimal. Agar kegiatan pembelajaran dapat berhasil dengan baik, maka seorang guru hendaknya selalu aktif dalam melibatkan siswa selama kegiatan pembelajaran berlangsung.Seorang guru hendaknya trampil dan dapat menguasai berbagai metode pembelajaran agar siswa tidak bosan dan lebih mudah memahami materi pelajaran.Hendaknya guru selalu memotivasi siswa agar membaca dulu di rumah tentang materi yang akan dibahas pada pertemuan berikutnya, supaya dalam pembelajaran siswa memiliki gambaran materi yang akan dibahas berikutnya.Terkait dengan penelitian ini hendaknya dikembangkan lagi instrument-instrumen penelitian seperti angket dan lembar pengamatan kolaborator sehingga data yang kita peroleh dapat memberikan gambaran utuh tentang pelaksanaan pembelajaran yang kita laksanakan.

\section{DAFTAR PUSTAKA}

Dini R. 2005. Pengantar Dasar Matematika. Diktat Program Studi Matematika STKIP PGRI Blitar.

Djuweni. 2005. Penelitian Tindakan Kelas. Makalah disajikan dalam acara peningkatan Profesionalisme Guru, 
Dikdas Kota Blitar, SMP / SMA se Kota Blitar, Maret 2005

Dimyati, Mudjiono. 1998. Belajar Pembelajaran. Jakarta : Asdi Mahasatya.

Milyasa, E. 2004. Implementasi Kurikulum 2004( Panduan Pembelajaran KBK ). Bandung : Rosdakarya.

Nurhadi, Yasin BY, Senduk AG. 2004. Pembelajaran Kontekstual dan Penerapan dalam KBK. Malang : Universitas Negeri Malang.PPGM. 1999. Pembelajaran Matematika Yang Aktif dan Efektif. Yogyakarta : Pusat Pengembangan Penataran Guru

Riki Suliana. 2005. Dasar - dasar dan Proses Pembelajaran. Blitar Program Studi Matematika STKIP PGRI Blitar.

Suryabrata S, 1984. Psikologi Pendidikan. Yogyakarta : Rajawali Pers.

Suryabrata S, 2003. Metodologi Penelitian. Yogyakarta : Rajawali Pers.

Soesianto F, Dwijono D. 2003. Logika Proposisional.Yogyakarta: Andi.

Tim Penyusun Intan Pariwara, 2004. Matematika Untuk SMA Jilid 1b. Klaten. Intan Pariwara ( 3 - 32 )

Wirodikusumo, Sartono. 2004. Matematika untuk SMA Kelas X. Jakarta: Erlangga $(123-189)$

2003. Kurikulum 2004.

Standart Kompetensi Mata pelajaran Matematika SMA dan MA. Jakarta: Depdiknas (15). 